\title{
일반계 고등학생의 학업 스트레스, 희망, 내재적 동기, 학업 소진의 구조적 관계 및 성별차이 탐색
}

\section{논문 요약}

본 연구의 목적은 일반계 고등학생을 대상으로 학업스트레스가 학업소진에 이르는 과정에서 개인의 심리 내 적 특성인 내재적 동기와 희망의 구조적 관계를 탐색하는 것이다. 또한 이들 변인들 간의 구조적 관계가 성별에 따라 어떠한 차이가 있는지 확인하고자 하였다. 이를 위해 경기, 영남, 호남 지역 일반계 남녀 고등학생 443명의 설문응답 결과를 분석하고, 학업스트레스와 학업소진간의 관계를 내재적 동기와 희망이 매개하는 것으로 가설모 형을 설정하여 내재적동기와 희망과의 관계에 방향을 설정한 2 가지 경쟁모형과 비교하였다. 그 결과 학업스트레 스가 학업소진에 미치는 직접적인 영향력이 확인되었고, 학업스트레스가 학습자의 희망을 거쳐 내재적 동기에 영향을 주어 학업소진에 이르게 되는 간접경로의 통계적 유의성이 확인되었다. 그리고 학업스트레스에서 희망으 로 가는 경로계수에서 남학생보다 여학생의 학업스트레스가 희망에 더 부정적인 영향을 주는 것으로 나타나 성 별간의 유의한 차이가 확인되었다. 이러한 결과는 일반계 고등학생의 학업 스트레스가 학업 소진으로 이어지는 정도를 줄이기 위해 주목해야 할 여러 가지 변수 중 희망과 내재적 동기도 포함되어야 함을 시사한다. 


\section{I. 서론}

이 연구는 세계적으로 공부를 가장 오랜 시간 동안 하고 높은 학업성취도를 내면서도, 미래를 꿈꿀 시간이 없고 학업에 대한 자신감과 행복감이 낮은 우리나라 학생들(한국교육과정평가원, 2014)의 지속적인 학업스트레스와 학업소진을 좀 더 구체적으로 이해하기 위해 수행되었다. 우 리나라 고등학생 중 $73.6 \%$ 가 전반적인 생활에서 스트레스를 경험하며, 주요 스트레스원이 공부 와 성적(65.2\%)으로 나타났다(통계청, 2010). 이러한 상황은 고등학생들이 경험하는 여러 가지 스트레스 중 학업 스트레스가 가장 높다는 선행 연구들(고홍월, 2012; 모상현·김미영, 2009; 손향 숙, 2002; 이자영, 2010b; 황혜정, 2006)을 통해서도 지속적으로 지적되어 왔다. 고등학생 시기에 는 치열한 대학 입시경쟁을 치러야 하므로 학업스트레스의 강도는 어느 시기보다 더 클 수밖에 없고 누적된 학습문제와 스트레스는 학업소진으로 이어질 수 있다. 학업 스트레스와 학업소진은 학업 자체에 대한 태도를 넘어서서 개인의 전반적인 삶의 태도 뿐 아니라 신체적·정신적 건강에 까지 악영향을 미치는 심각한 현상이다(고홍월, 2012; 문경숙, 2006; Bakker et al., 2000; Yang, 2004).

스트레스는 인간과 환경 사이의 상호작용적 관계에서, 자신의 자원을 지속적으로 요구 받거 나 자신이 소유한 자원의 양을 초과하여 요구받음으로 인해, 개인의 안녕상태가 위협받는다고 판단될 때 느끼는 인간의 경험과 행동이다(Lazarus \& Folkman, 1984). 학업스트레스는 개인이 이용할 수 있는 적응적 자원을 초과하여 부과되는 학업 관련 요구의 산물(Wilks, 2008)이며, 성 적, 수업, 공부 등 학업과 관련된 일로 부모, 교사, 자기 스스로의 압력에 의해 학생들이 고민하 고 괴로워하는 심리적 불균형 상태이다(박병기.박선미, 2012). 고등학생은 대학 진학을 앞두고 입시로 인한 부담감이나 불안을 느끼기 때문에 학업스트레스의 강도는 더 클 수밖에 없으며 이 로 인해 불안(한태영, 2005)이나 우울, 자살생각 등의 정신 건강 문제뿐만 아니라, 성장 호르몬 분비 감소로 인한 성장장애, 두통, 소화불량, 불면증 등의 신체적 증상과 사회적 위축을 경험하 기도 한다(고재홍윤경란, 2007; 신현숙 외, 2005; 이경숙·김정호, 2000). 한편 학업스트레스는 우 울, 자살 등의 문제에 직접적으로 영향(이지현.이정윤, 2009)을 미치는 것이 아니라 학업소진을 통해 나타난다는 연구들은(Koeske \& Koeske, 1991) 학업스트레스가 학생들에게 치명적인 악영 향을 미치기 전에 학업소진 감소에 관심을 둘 것을 요청하고 있다.

학업소진(academic burnout)은 과도한 학업으로 인해 피로감, 좌절감, 학업에 대한 거리감, 스 트레스, 정신적 소모감, 무력감, 냉소적인 태도 등을 나타내는 신체적, 정서적, 정신적 고갈 상태 (이영복·이상민·이자영, 2009)를 나타내는 개념이다. 학업소진은 장기간에 걸친 학업스트레스와 학업에 대한 부담으로 인해 야기되며, 학업소진을 경험하는 학생들은 학업에 대한 냉소적 태도 와 무능감을 보이고 실패에 대처하는 노력과 능력이 약하며(고홍월, 2012), 우울, 강박, 불안과 
같은 심리적 증상(이은희·최태산·서미정, 2000; 한태영, 2005; Bakker et al., 2000; Koeske \& Koeske, 1991)과 자살생각(고재홍·윤경란, 2007; 문경숙, 2006; 이지현·이정윤, 2009)이 증가하고, 결석률이 높아져 학업중단상태에 놓이기도 한다(전혜진·김영갑, 2011; Meier \& Schmeck, 1985; Ramist, 1981; Yang, 2004). 특히 우리나라 일반계 고등학생들은 '성공적인 대학입시'라는 거대하 고 유일한 생애최초의 과제를 눈앞에 두고 높은 학업성취에 대한 내외적 압력을 경험하면서 노 력에 비해 오르지 않는 성적으로 인해 좌절하기도 하고, 반복적인 좌절에 기진맥진하게 되어 학 업에 대한 무능감, 반감, 냉소적인 태도 즉 소진을 경험하는 상황에 놓이기 쉽다.

소진현상을 설명하는 대표적인 모형으로는 요구-통제모형(CDM: Deman-Control Model)과 노력-보상 불균형모형(ERIM: Effort-Reward Imbalance Model)이 있다. 요구-통제모형은 많은 양의 직무에 대처해 나갈 수 있는 적절한 통제력이 제공되지 않을 경우 과도한 소진이 야기된다 고 설명하며, 노력-보상 불균형 모형은 개인이 기울인 노력에 비해 자기 존중이나 인정, 보상 등을 받지 못한다고 지각할 때 소진이 일어난다고 설명한다. 요구-통제 모형(Karasek, 1979)에 따르면, 우리나라 고등학생들은 과다한 학업을 수행해야 하는 높은 학업요구를 받고 있지만 학 업에 대한 학업 분량이나 시간을 조절하는 재량권을 가지고 있지 못하므로 통제감이 낮아 소진 유발상황에 놓이게 된다(김민애 외, 2010; 남상필·이지연·장진이, 2012, 이은영, 2014). 노력-보상 불균형모형(Siegrist et al, 1990)에 따르면, 우리나라 고등학생들은 노력한 만큼 성적이 쉽게 오 르지 않거나 또는 자녀가 거둔 학업성취에 대하여 쉽게 만족하지 않고 더욱 높은 성취도를 기대 하는 부모를 둔 경우가 많아서, 노력에 비해 적절한 보상이 주어지지 않는데 따르는 소진을 경험 할 가능성이 있다(Bellingrath, Weigl, \& Kudieka, 2008; Li, Yang, \& Cho, 2006). 즉, 우리나라 청소년들은 요구-통제모형과 노력-보상 불균형 모형 모두에서 소진에 이를 우려가 높은 취약한 상황에 놓여있다고 볼 수 있다.

그러나 지속적이고 강한 학업스트레스가 학업소진으로 이르기 전에 완충역할을 하는 요인들 이 있음을 암시하는 연구들도 상당히 진행되었다. 예를 들어, 자아탄력성은 스트레스와 안녕감 의 관계(강명희, 이수연, 2012) 및 스트레스와 자살생각의 관계(고재홍, 윤경란, 2007)를 매개하 는 것으로 나타났다. 과도한 학업요구와 학업소진 사이를 자아존중감이 매개한다는 것을 보여주 는 연구(김영실, 2012)가 있으며, 학업동기(이자영, 2010a; 조한익·이현아, 2010)와 희망(강명희, 2013; 김남희, 2006; 이희경, 2007; 조한익, 2012) 또한 학업스트레스와 학업소진의 관계를 매개할 수 있다는 가능성을 밝힌 연구들도 있다. 조한익과 이현아(2010)는 완벽주의와 학업소진 간의 관계를 수행회피목표가 완전 매개함을 검증하였으며, 몇몇 연구들은 희망이 심리적 안녕감에 중 요한 자원일 뿐 만 아니라(김남희, 2006; 이희경, 2007; 조한익, 2011), 학업스트레스와 심리적 안 녕감 간의 관계를 매개한다는 것을 보여주었다(강명희, 2013). 이 외에도 부모의 기대(신병창, 2012), 양육태도(한은아 외, 2011), 유대감(신혜진·유금란, 2014) 등의 개인외적 변인들 또한 학업 
스트레스와 학업소진의 관계를 매개하거나 조절할 수 있음이 밝혀졌다.

학업스트레스와 학업소진의 관계를 매개할 가능성이 있는 여러 가지 변인들 중 본 연구에서 주목하고자 하는 것은 희망과 내재적 동기이다. 희망은 목표를 명확하게 정의하고 (goal-thinking), 목표에 도달하기 위한 구체적인 전략을 수립하며(pathway thinking), 그리고 수 립한 전략들을 사용하여 목표를 추진하고 유지하기 위한 역량(agency thinking)을 발현하는데 필요한 인간의 긍정적인 에너지이다(Snyder, 2002; Snyder, Harris, et al., 1991). 희망은 개인이 어떻게 자신의 목표를 성공적으로 이루고자 노력하는가에 대한 보다 폭넓은 설명을 제공한다 (Padilla-Walker, Hardy, \& Christensen, 2011). 청소년을 대상으로 한 연구에서 희망은 약물남용 (Carvajal, Clair, Nash, \& Evans, 1998), 폭력과 공격(Bolland, 2003), 성행동(Chang et al., 2003), 자기 존중감, 삶의 만족, 학업성취를 예언하였고(Adelabu, 2008; Barnum et al., 1998; You et al., 2008), 사회적지지(Bland \& Darlington, 2002), 내외통제성(Bunston, Mings, Mackie, \& Jones, 1995), 종교(Ciarrocchi, Dy-Liacco, \& Deneke, 2008)등에 의해 예언되었다. 또한 희망은 청소년 의 사회적 지지와 일반적인 안녕감을 매개하였고(Yarcheski, Mahon, \& Yarcheski, 2001), 사회적 지지와 긍정적인 건강행동 사이를 매개하는 것으로도 밝혀졌다(Mahon, Yarcheski, \& Yarcheski, 2004).

청소년의 학업과 관련한 희망 연구는 비교적 덜 이루어졌지만, Snyder 등(2002)은 희망이 높 은 학생들은 목표를 향한 다양한 경로를 만드는 능력과 학업적 문제해결 능력이 높아 과제수행 상황에서 불안이 적고, 환경에 대한 통제감이 높아 내적으로 쉽게 동기화되어 학업수행 및 성취 가 높음을 보여주었다. 조한익(2012)의 연구에서 희망은 수행접근동기 및 숙달접근동기와 학교 생활적응의 관계를 매개하였고, 장은주와 이종연(2014)의 연구에서 희망은 학업적 자기효능감과 대처능력을 높이고, 학업성취도와 주관적 안녕감에도 영향을 미치는 것으로 나타났으며, 진승하 와 신희천(2010)의 연구에서는 희망이 스트레스와 우울의 관계를 조절하였다. 이와 같이 희망은 많은 연구들에서 개인의 주관적 안녕감을 증진시키는 긍정적 특질이며, 시련이나 스트레스 상황 에서 완충역할을 해주는 것으로 밝혀지면서, 청소년의 학업 스트레스와 소진 사이의 관계를 매 개할 가능성이 존재하지만 아직 그 역할을 직접적으로 규명한 연구는 찾아보기 어렵다.

내재적 동기는 개인이 관심을 가지는 영역에서 과제에 몰두하는 것 자체에 기쁨을 느끼고, 과제완수를 향한 최적의 도전을 추구하고 달성하려는 성향(Deci \& Ryan, 1985)이며, 심리적 욕 구, 개인적 호기심, 타고난 성장을 향한 노력으로부터 자발적으로 생기는 것이다(Reeve, 2006). 내재적 학업동기는 특별한 외적 보상이 없더라도 학습하려는 내용에 관심과 흥미가 있기 때문 에 학습하려고 하는 경향이며, 학습상황에서 개인의 활력을 증가시키고, 자존감, 집중력, 긍정적 영향력 등을 촉진한다(Ryan \& Connell, 1989). 내재적 동기는 자신을 어느 정도로 그 행동의 주 체로 지각하느냐에 따라 결정되므로 지속적인 학습이 요구되는 상황에서도 학습에 대한 내재적 
동기가 높은 학습자는 학습에 대한 열정과 학업스트레스에 대한 통제감을 유지하여 학업소진을 덜 경험할 수 있다. 선행연구에서 내재적 동기와 학업스트레스는 부적 상관, 학업적 자기 효능감 과는 정적 상관을 보여주었다(이민희·정태연, 2007; 정지영·김희화, 2010; 조정은, 2011). 또한 내 재적 동기가 높을수록 학업 성취도가 높아지고(안도희·최혜림, 2012), 내재적 동기를 포함한 자 율동기 유형이 학업 소진과 유의미한 부적 상관을 보이고 있었다(고홍월, 2012). 이와 같은 선행 연구 결과들은 내재적 동기가 학업스트레스와 학업소진의 관계를 매개할 수 있을 것임을 시사 한다.

이와 같이 지속적이고 강한 학업스트레스는 학업소진을 유발하지만, 학업스트레스가 심한 상 황에서 다양한 대안을 통해 목표에 이를 수 있다고 긍정적으로 인지하는 희망이 있거나, 외적보 상보다 과제자체에 대한 관심을 유지하는 내재적 학습동기가 있다면, 학업스트레스가 학업소진 에 미치는 부정적인 영향은 다소 감소될 것으로 기대할 수 있다. 이에 본 연구에서는 학업스트레 스가 학업소진에 미치는 영향과 아울러 희망과 내재적 동기가 둘 간의 관계를 매개하는지에 대 하여 탐색하고자 한다.

한편 본 연구에서 주목한 두 개의 매개변인인 내재적 동기와 희망 사이의 관계에 대한 방향 을 이론적으로 결정할 만큼 충분한 선행연구를 찾아보기는 쉽지 않았다. 희망이 가난한 유색인 종 학생들의 학업동기에 유의하게 영향을 미치며(Juntnen \& Wettersen, 2006), 중학생의 성취동 기, 진로장벽, 진로태도성숙에 영향을 미친다는 연구(김향란, 2012), 또는 희망 증진 집단상담을 실시한 결과 중학생의 학업동기가 증진되었다는 연구결과(박문규, 이영순, 2011)는 희망이 학업 동기를 유발할 수 있음을 시사한다. 그러나 어머니로부터 받은 충분한 지지가 청소년의 희망을 높여준다는 연구(Davis-Maye \& Perry, 2007)와 희망이 지지적인 성인과의 안전한 관계에서 발 달된다는 것을 밝힌 연구(Shorey et al., 2003)들은 내재적 동기가 증가될 수 있는 자율적이고 지지적인 환경에서 희망이 유발할 수 있음을 시사하여, 희망과 내재적 동기의 관계의 방향은 계 속적으로 탐색해 볼 필요가 있다.

이에 본 연구에서는 희망과 내재적 동기가 학업스트레스와 학업소진의 관계를 매개한다고 가 정하여 가설모형으로 설정하고, 희망이 내재적 동기에 영향을 미치는 모형과 내재적 동기가 희 망에 영향을 미치는 모형 두 가지를 경쟁모형으로 설정하여 가설모형과 두 가지 경쟁모형 들 간의 적합도 및 경로의 유의성을 비교하고자 한다.

아울러 본 연구에서는 학업스트레스, 내재적 동기, 희망, 학업소진의 구조적 관계가 성별에 따라 달라지는지에 대하여 살펴보고자 한다. 국내 고등학생을 대상으로 실시한 학업스트레스의 남녀차이 연구를 살펴보면, 여학생이 남학생보다 전반적인 학업스트레스가 유의하게 높지만(김 미경 외, 2012; 김현희, 2009), 고3 인 경우 남학생이 부모와 친구관련 스트레스가 높게 나타나(조 강래, 2007) 스트레스의 성별 차이는 명확히 규명되지 않았다. 또한 성적과 학업스트레스의 관계 
에 대한 성별의 조절효과 분석에서는 여학생이 남학생에 비해 학업성적에 따라 영향을 많이 받 는 것으로 나타났다(김미경 외, 2012). 내재적 동기의 성별 차이 분석에서는 중학생의 경우에서 여학생이 남학생보다 내재적 동기가 높았고(명혜원, 1999), 남학생 집단이 여학생 집단보다 희망 이 낮았다(조한익, 2010; Kenny et al., 2010). 학업소진은 여학생이 남학생보다 전반적으로 높게 나타나고 있으나(Kiuru, Aunola, Nurmi, Leskinen,\& Salmela-Aro, 2008), 초등학생을 대상으로 한 연구에서는 회피, 정서적 소진, 신체적 소진에서 남학생이 여학생보다 높은 소진 경향성을 보여주었다(조주연·김명소, 2013). 이와 같이 성별차이에 대한 연구 결과들은 아직 서로 다른 결 과들을 내는 소수의 연구만이 진행되어 있어서, 대체적인 경향을 파악하기 위해서는 보다 많은 자료들이 축적될 필요가 있다. 성별에 따라 학업스트레스 상황이 희망이나 내재적 동기에 미치 는 영향력이 달라진다면 학업소진을 방지하기 위한 차별적이고 효과적인 방안들을 도출하는 데 유용한 기초자료가 될 수 있을 것이다.

이와 같은 논의를 바탕으로 설정한 본 연구의 문제는 다음과 같다.

연구문제 1. 고등학생의 학업스트레스, 희망, 내재적 학업동기, 학업소진의 구조적 관계는 어 떠한가?

연구문제 2. 고등학생의 학업스트레스, 희망, 내재적 학업동기, 학업소진의 구조적 관계에는 성별 차이가 있는가?

\section{․ 연구 방법}

\section{1. 연구대상}

경기, 영남, 호남 지역에 소재한 인문계 고등학교(남녀공학)에 재학 중인 학생들을 대상으로 총 500 여 부의 설문지를 배포하였다. 일반계 고등학교 교사들을 섭외하여, 연구의 목적과 취지 를 설명한 후 우편으로 검사지를 발송하고 우편으로 수령하였다. 설문지 배포 및 수령은 2014년 5월 초부터 말까지 이루어졌으며 수거된 설문지들 중 불성실하게 응답하거나, 응답하지 않은 문 항이 있는 설문지를 제외한 443 명의 설문지를 분석에 사용하였다. 연구대상의 성과 학년분포는 <표 $1>$ 과 같다. 
<표 1> 연구대상

\begin{tabular}{|c|c|c|c|c|c|}
\hline & & \multicolumn{3}{|c|}{ 학년 } & \multirow{2}{*}{ 전체 } \\
\hline & & 1 & 2 & 3 & \\
\hline \multirow{2}{*}{ 성별 } & 남 & $67(44.37)$ & 83(52.53) & $72(53.73)$ & $222(50.11)$ \\
\hline & 여 & $84(55.63)$ & $75(47.47)$ & $62(46.27)$ & 221(49.89) \\
\hline \multicolumn{2}{|c|}{ 전체 } & 151 & 158 & 134 & 443 \\
\hline
\end{tabular}

\section{2. 측정도구}

1) 학업스트레스 척도

연구대상의 학업스트레스를 측정하기 위해 박병기와 박선미(2012)가 중학생을 대상으로 타당 화한 학업스트레스 척도 중 자기스트레스 척도를 사용하였다. 이 척도는 성적스트레스, 수업스 트레스, 공부스트레스로 구성된 6점 리커트 척도이다. 성적스트레스는 학업(수업, 공부)의 결과 로 인해 받는 학업스트레스를 나타내는 4 문항(문항 예: 열심히 공부해도 성적이 오르지 않으면 괴롭다), 수업스트레스는 학교에서 정해진 과정과 시간에 배우면서 받는 학업스트레스를 나타내 는 4문항(문항 예: 수업 시간이 되면 다른 생각이 나서 괴롭다), 공부스트레스는 스스로 학문을 익히면서 받는 학업스트레스를 나타내는 4 문항으로 이루어졌다(문항 예: 해야 할 공부 양이 많 아 답답하다). 각 영역에서 높은 점수를 받을수록 스트레스가 높아지는 것을 의미한다. 본 연구 에서 분석한 자기스트레스 하위 요인별 신뢰도는 성적스트레스 .91, 수업스트레스 .84, 공부스트 레스 .85 이다.

\section{2) 학업동기 척도}

연구대상의 학업동기를 측정하기 위해 중고등학생용 학업동기척도(이민희.정태현, 2007)를 사 용하였다. 이 척도는 공부할 때, 시험 공부할 때, 성적표를 받았을 때의 느낌이나 생각 그리고 공부하는 이유에 대한 개방형 질문지를 통해 예비조사를 실시한 내용분석 및 Ryan과 Connell(1989), 김아영과 오순애(2001), 고경희(2003), 박병기 외(2005)의 척도에서 선별한 68문항 을 타당화하여 개발되었으며, 최종 5 요인 26 문항으로 구성되어 있다. 본 연구에서는 6 문항으로 구성된 내재적 동기 요인을 사용하였으며, 학습활동에 참여하게 됨으로써 얻게 되는 즐거움과 만족감 혹은 학습활동 그 자체에 역점을 두는 정도를 측정한다(문항 예: 잘 모르는 것을 알았을 때 기쁨을 느끼곤 한다). 원척도가 5점 리커트 척도였으나 본 연구에서는 다른 척도와의 통일성 
을 위하여 6점 척도로 제시하였다. 높은 점수를 받을수록 내재적 동기가 높다는 것을 나타내며, 본 연구에서 검증한 내재적 동기 척도의 신뢰도는 87 이다.

3) 희망 척도

연구대상의 희망수준을 측정하기 위해 Snyder 등(1996)의 상태희망척도를 한국 학생에게 타 당화한 것을 사용하였다(강이영, 2002). 상태희망척도는 특정 시점의 목표 지향적 사고를 평가하 는 척도로서(송주영, 이희경, 2013), 주도사고 3문항, 경로사고 3문항으로 구성되어 있다. 주도사 고는 개인으로 하여금 지속적으로 목표를 향해 나아갈 수 있게 하는 동기적 에너지를 측정하며 (문항 예: 현재 나는 내 목표를 의욕적으로 추진하고 있다), 경로사고는 목표달성을 위해 여러 가지 가능한 방법을 생성하는 것과 그러한 능력에 대한 지각을 측정한다(문항 예: 나는 현재 목 표를 달성하기 위해 많은 방법을 생각할 수 있다). 원 척도는 8점 리커트 척도인데 본 연구에서 는 다른 척도와 통일성을 위해 6점 척도로 제시하였고, 각 요인에서 높은 점수를 받을수록 희망 수준이 높다는 것을 나타낸다. 본 연구에서 분석한 하위요인별 신뢰도는 경로사고 .77, 주도사고 .80 이다.

4) 학업소진 척도

연구대상의 학업소진 정도를 측정하기 위해 이자영(2010b)의 한국형 학업소진척도(KABI: Korea Academic Burnout Inventory)를 사용하였다. 이 척도는 Schaufeli 등(2002)이 개발한 MBI-SS(Maslach Burnout inventory-Student Survey: Maslach \& Jackson, 1981)를 이영복 외 (2009)가 타당화한 것을 바탕으로 한국의 초, 중, 고등학생에게 타당화한 것이다. 한국형 학업소 진척도는 탈진, 냉담, 무능감, 반감의 4 요인 각 5 문항씩 총 20 문항으로 구성된 6점 리커트 척도이 다. 탈진은 공부로 인해 지치는 것과 관련된 내용이고(문항 예: 나는 학교수업이 끝나고 집에 돌아오면 완전히 지친다), 냉담은 공부에 대한 회의적인 태도와 관련된 내용이며(문항 예: 나는 공부가 나의 미래에 도움이 될지 의심스럽다), 무능감은 공부에 대해 자신감이 없는 것과 관련된 내용이고(문항 예: 나는 공부를 아무리 열심히 해도 안된다), 반감은 공부를 싫어하는 감정을 의 미한다(문항 예: 나는 공부가 중요한 세상이 싫어진다). 본 연구에서 검증한 하위요인별 신뢰도 는 탈진 .89 , 냉담 .87 , 무능감 .87 , 반감 .89 이다. 


\section{3. 자료 분석}

수집된 자료는 SPSS 18.0, AMOS 프로그램을 사용하여 각 변인의 기술 통계치와 변인간의 관계, 구조모형의 적합도, 그리고 경로계수를 파악하였다. 측정치들이 다변량 정규성 가정을 만 족하므로 최대우도법(Maximum Likelihood)을 사용하여 모수치를 추정하였고, 확인적 요인분 석을 통해 측정모형 및 구조모형이 자료에 적합한지 확인하였으며, 모형의 적합도를 판단하기 위해 $X^{2}, \mathrm{GFI}, \mathrm{CFI}, \mathrm{TLI}, \mathrm{RMSEA}$ 의 적합도 지수를 사용하였다.

\section{III. 연구 결과}

\section{1. 측정변인들의 기술통계치 및 상관관계}

본 연구에서 측정한 변인들의 평균, 표준편차 및 왜도, 첨도는 <표 $2>$ 와 같다. 모든 변인의 왜도와 첨도가 모두 1.0 이하로 정규분포 가정에서 벗어나지 않는 것으로 나타났다. 또한 변인간 의 다중공선성이 존재하는지 알아보기 위해서 종속변인을 학업소진으로 하여 독립변인들 간의 상관관계를 살펴본 결과 분산팽창계수(VIF<1.5)와 공차한계도 안정적이어서 본 자료는 정규분 포의 가정을 만족시켜주었다. 측정변인들의 상관행렬은 <표 3>과 같이 나타났으며, 대부분 유의 한 정적 또는 부적 상관관계( $p<.01$ 또는 $p<.05)$ 를 보이고 있으나, 내재적 동기와 학업스트레스의 하위요인인 성적스트레스의 상관관계가 유의하지 않게 나타났다. 즉, 학업스트레스와 내재적 동 기, 학업스트레스와 희망, 내재적동기와 학업소진, 희망과 학업소진 간에는 유의한 부적 상관 (-.15 -.31)이 있음을 알 수 있고, 내재적 동기와 희망, 학업스트레스와 학업 소진 간에는 유의한 정적 상관(.45 .68)이 있음을 알 수 있다.

<표 2> 측정변인들의 기술통계치

\begin{tabular}{ccccrr}
\hline \multirow{2}{*}{ 잠재변인 } & 측정변인(1-6점) & 평균 & 표준편차 & 왜도 & 첨도 \\
\hline \multirow{3}{*}{ 학업소진 } & 무능감 & 3.07 & 1.09 & .207 & -.588 \\
\cline { 2 - 6 } & 반감 & 4.33 & 1.15 & -.616 & .150 \\
\cline { 2 - 6 } & 탈진 & 3.45 & 1.22 & .090 & -.562 \\
\cline { 2 - 6 } & 냉담 & 3.20 & 1.18 & .365 & -.262 \\
\hline \multirow{2}{*}{ 희망 } & 주도사고 & 3.50 & 1.07 & .046 & -.178 \\
\cline { 2 - 6 } & 경로사고 & 4.10 & 0.88 & -.190 & -.013 \\
\hline
\end{tabular}




\begin{tabular}{ccccrr}
\hline 잠재변인 & 측정변인(1-6점) & 평균 & 표준편차 & 왜도 & 첨도 \\
\hline \multirow{3}{*}{ 학업스트레스 } & 성적스트레스 & 4.02 & 1.32 & -.583 & -.271 \\
\cline { 2 - 6 } & 수업스트레스 & 3.18 & 1.15 & .171 & -.435 \\
\cline { 2 - 6 } & 공부스트레스 & 3.98 & 1.25 & -.463 & -.427 \\
\hline \multirow{3}{*}{ 내재적 동기 } & 문항1 & 3.86 & 1.26 & -.288 & -.387 \\
\cline { 2 - 6 } & 문항2 & 4.14 & 1.28 & -.723 & .173 \\
\cline { 2 - 6 } & 문항3 & 3.67 & 1.41 & -.232 & -.698 \\
\cline { 2 - 6 } & 문항4 & 4.03 & 1.37 & -405 & -.467 \\
\cline { 2 - 6 } & 문항5 & 3.70 & 1.41 & -.290 & -.675 \\
\cline { 2 - 5 } & 문항6 & 3.67 & 1.28 & -.253 & -.390 \\
\hline
\end{tabular}

\section{2. 측정모형 검증}

구조모형 분석에 앞서 측정모형에 대한 확인적 요인분석 결과 측정모형이 적합한 것으로 나 타났다 $\left(X^{2}=321.003(d f=81, p \times .01), \mathrm{GFI}=.914, \mathrm{CFI}=.918, \mathrm{TLI}=.907, \mathrm{RMSEA}=.082\right)$. 한편 학업스트 레스의 하위요인들은 .70-.85의 요인부하량을 보였으며, 상태희망의 하위요인들은 .76-.86의 요인 부하량, 내재적 동기는 .68-.79의 요인부하량, 학업소진의 하위요인들은 .67-79의 요인부하량을 지닌 것으로 나타났다. 하위요인들의 요인부하량은 모두 $p<.01$ 수준에서 유의하였다. 따라서 15 개의 측정변수로 4 개의 이론적 잠재변수를 구인한 것은 타당하다고 할 수 있다.

\section{3. 구조모형 분석}

선행연구를 바탕으로 학업스트레스, 내재적 학업 동기, 희망, 학업소진의 관계에 대해 모형을 설정하여 적합도를 비교하였다. 가설모형은 내재적 동기와 희망이 각각 학업스트레스와 학업소 진의 관계를 매개하는지 살펴보기 위한 것이며, 경쟁모형은 정적 상호상관(표 3참조)관계를 갖 는 내재적 동기와 희망 두 변수 간 관계를 설정하고 관계의 방향에 따라 구조모형의 타당성이 달라지는지 확인하기 위한 것이다. 즉 경쟁모형 1 은 내재적 동기가 희망에 영향을 미친다는 경 로를 설정한 구조모형의 타당성을 살펴보기 위한 것이고, 경쟁모형 2는 희망이 내재적 동기에 영향을 미친다는 경로를 설정한 구조모형의 타당성을 살펴보기 위한 것이다.

\section{1) 가설모형}

가설모형은 학업스트레스와 학업소진의 관계에서 내재적 동기와 희망 각각이 매개효과를 갖 는지 탐색하기 위한 것이며, 수정지수를 이용하여 내재적 동기의 측정문항 1 번과 2 번, 3 번과 4 번 
<표 3> 측정변인들 간의 상관행렬

$(n=443)$

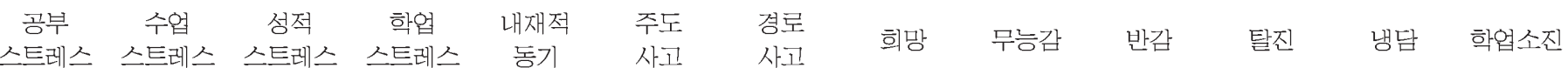

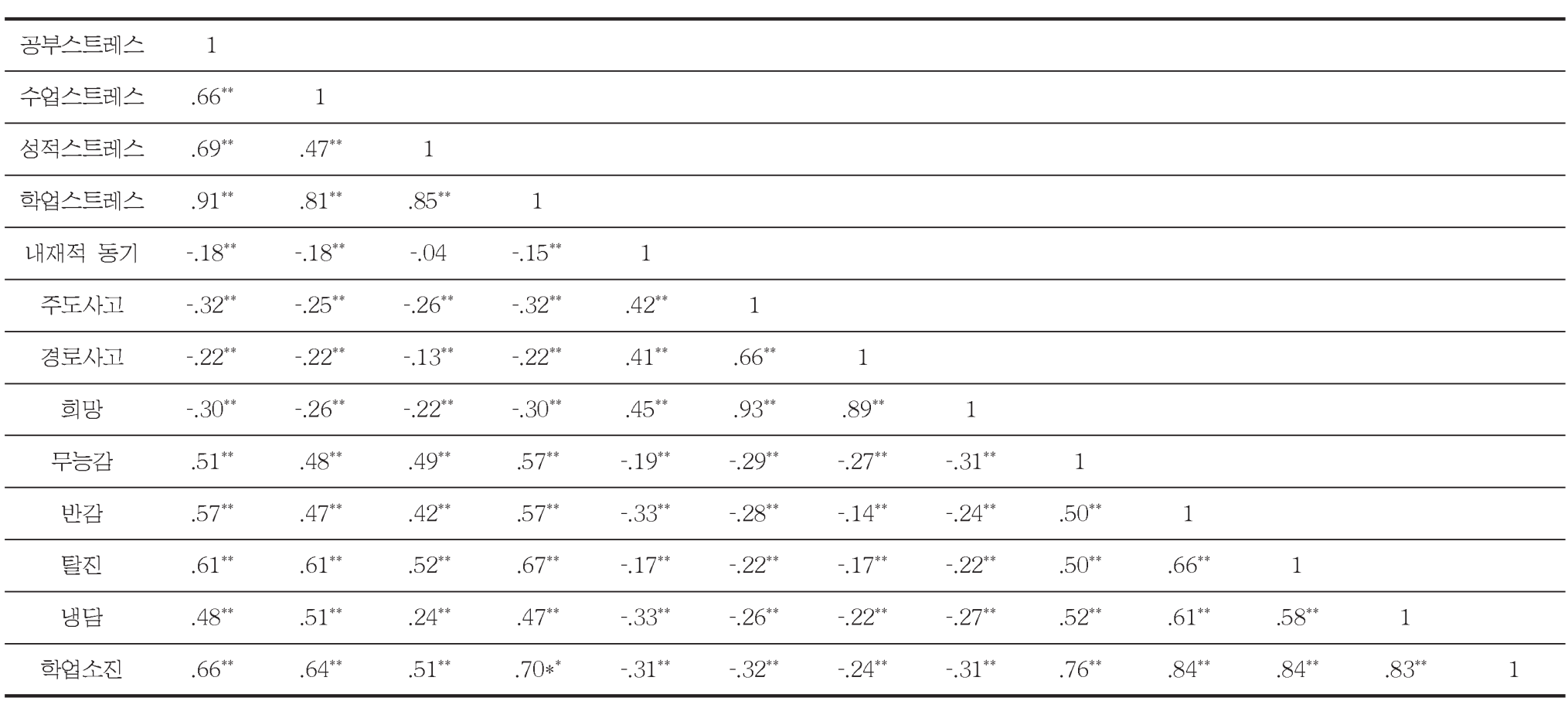

$* p<.05, * * p<.01$ 
의 오차 간 상관을 2 개 허용하였다. 가설모형의 적합도 지수는 $X^{2}=400.165(d f=82, p=.000)$, $\mathrm{CFI}=.904, \mathrm{TLI}=.842, \mathrm{RMSEA}=.194, \mathrm{GFI}=899$ 였으며, 경로계수 추정치에서 희망 $\rightarrow$ 학업소진의 경로가 유의하지 않았다. 또한 내재적 동기와 희망사이의 오차항 간의 수정지수(MI: Modification index)가 64.41로 나타나 내재적 동기와 희망사이의 관계 설정이 필요함을 시사하 였다.

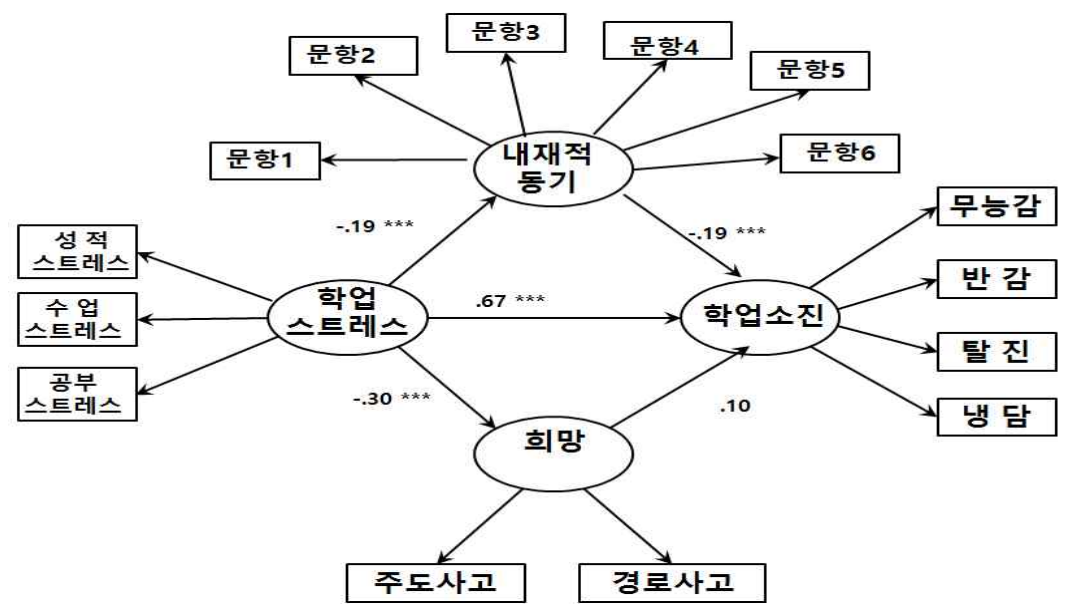

[그림 1] 가설 모형 (비표준화경로계수)

2) 경쟁모형 1

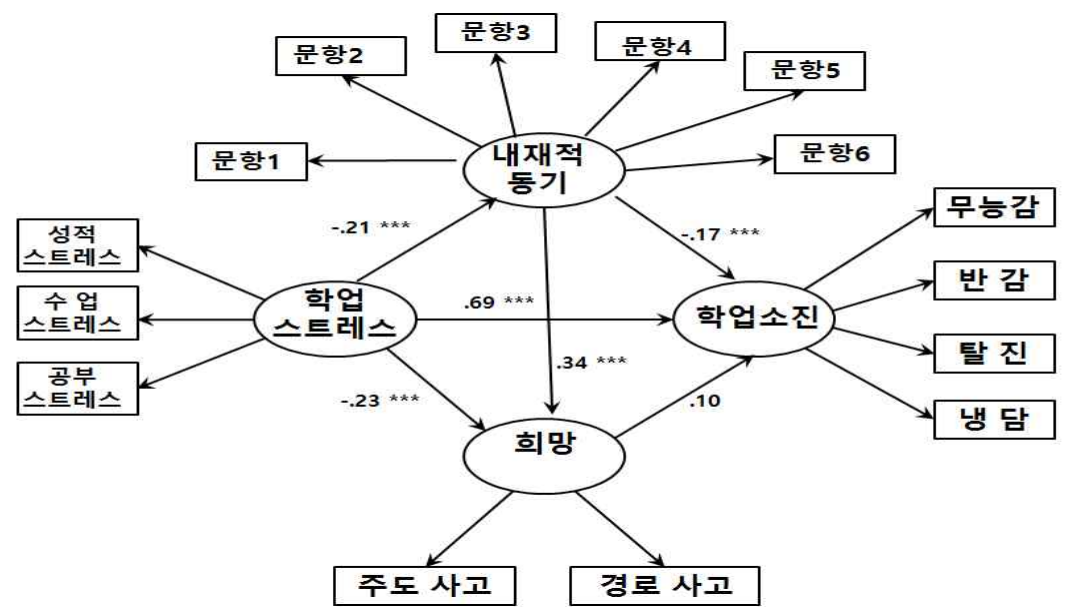

[그림 2] 경쟁모형 1(비표준화경로계수) 
경쟁모형 1 은 내재적 동기가 증가될 수 있는 자율적 환경에서 희망이 유발될 수 있음을 나타 내는 연구(Davs-Maye \& Perry, 2007; Shorey et al., 2003)에 기초하여 가설모형에 내재적 동기에 서 희망에 이르는 경로를 추가한 것이다. 경쟁모형 1 의 적합도 지수는 $X^{2}=323.799(d f=81$, $p=.000), \mathrm{CFI}=.927, \mathrm{TLI}=905, \mathrm{RMSEA}=.082, \mathrm{GFI}=.916$ 이며, 경로계수 추정치에서 희망 $\rightarrow$ 학업소 진의 경로가 유의하지 않고 양의 관계를 보이고 있다. 적합도 지수는 가설모형보다 향상되었고, 학업스트레스가 내재적 동기를 거쳐 학업소진에 이르는 경로를 보여주고 있으나, 학업스트레스 가 희망을 거쳐 학업소진에 이르는 경로는 타당하지 않은 것으로 나타났다.

3) 경쟁 모형 2

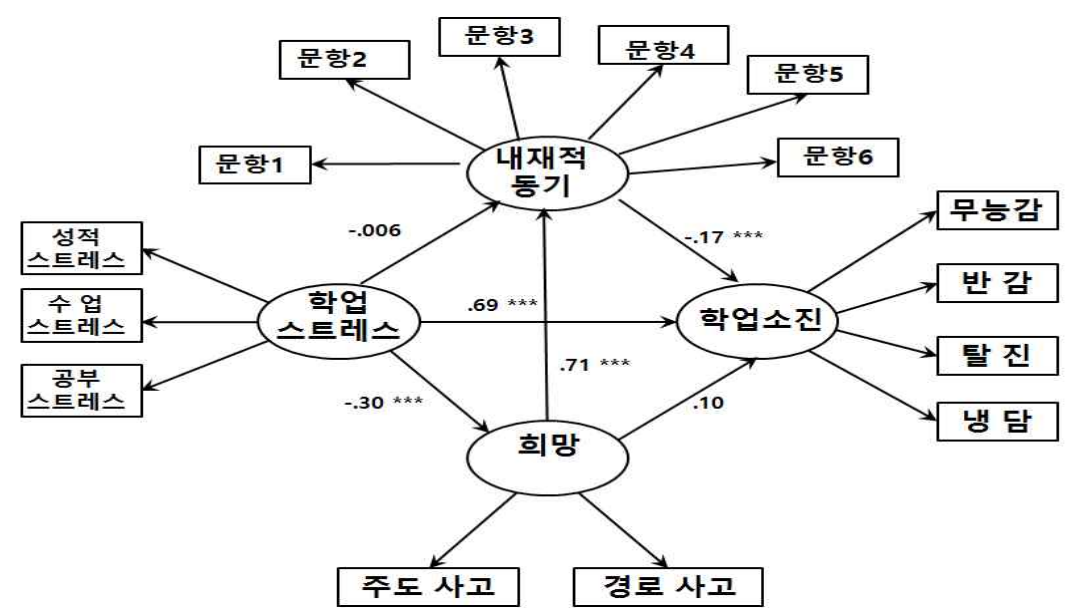

[그림 3] 경쟁모형 2(비표준화경로계수)

경쟁모형 2는 희망이 동기를 증진시킬 수 있음을 나타내는 연구(김향란, 2012; 박문규·이영순, 2011; Juntnen \& Wettersen, 2006)에 기초하여 가설모형에 희망에서 내재적 동기에 이르는 경로 를 추가한 것이다. 이 모형의 경로계수 추정치에서 학업스트레스 $\rightarrow$ 내재적 동기, 희망 $\rightarrow$ 학업소 진의 경로가 유의하지 않았다. 경쟁모형 2 의 적합도 지수는 경쟁모형 1 의 적합도 지수와 같으나 $\left(X^{2}=323.799(d f=81, p=.000), \mathrm{CFI}=.927, \mathrm{TLI}=905, \mathrm{RMSEA}=.082, \mathrm{GFI}=.916\right)$, 학업스트레스가 희망 과 내재적 동기를 거쳐 학업소진에 이르는 경로를 보여주고 있다. 희망과 내재적 동기의 경로의 방향이 경쟁모형 1 과 반대로 설정된 이 모형에서는 학업스트레스에서 내재적 동기에 이르는 경 로의 영향력이 감소되어 유의하지 않게 나타나고 있는데 이는 학업스트레스가 내재적 동기에 직접 영향을 주기보다는 희망을 통해 내재적 동기에 영향을 주고 있음을 보여주고 있다.

학업스트레스와 희망의 상관(-.30**), 희망과 학업소진의 상관( $\left.-.31^{* *}\right)$ 및 내재적 동기와 희망 
간의 상관(.45**)을 고려할 때, 경쟁모형 2에서 학업스트레스와 학업소진의 관계에 대한 희망의 영향력을 확인할 수 있었다. 이에 유의하지 않은 2 개의 경로를 제거한 후 $X^{2}$ 변화량의 유의도와 자유도를 비교한 결과 통계적으로 유의한 변화량을 보이지 않았고, 적합도 지수가 유사하여 2개 의 경로를 제거한 모형이 더욱 간명한 모형이므로 경쟁모형 2-1([그림 4] 참조)을 가지고 변인들 의 관계를 설명하고자 한다. 이 모형의 적합도 지수는 $X^{2}=326.806(d f=83, p=.000), \mathrm{CFI}=.927$, $\mathrm{TLI}=.907, \mathrm{RMSEA}=.082, \mathrm{GFI}=.915$ 로 나타났으며 모든 잠재변인들 간의 경로계수가 유의 $(p<.01)$ 하게 나타났다. 경쟁 모형 2-1에서 학업스트레스가 희망과 내재적 동기를 거쳐 학업소진에 이르 는 간접효과의 유의성을 검증하기 위해 부트스트레핑을 실시한 결과는 <표 $4>$ 에 제시되어 있으 며, 이 경로의 유의 확률은 .010로 나타나 통계적으로 유의함 $(p<.05)$ 을 알 수 있었다. 이는 학업스 트레스와 학업소진의 관계를 희망과 내재적동기가 부분 매개함을 나타내 준다.

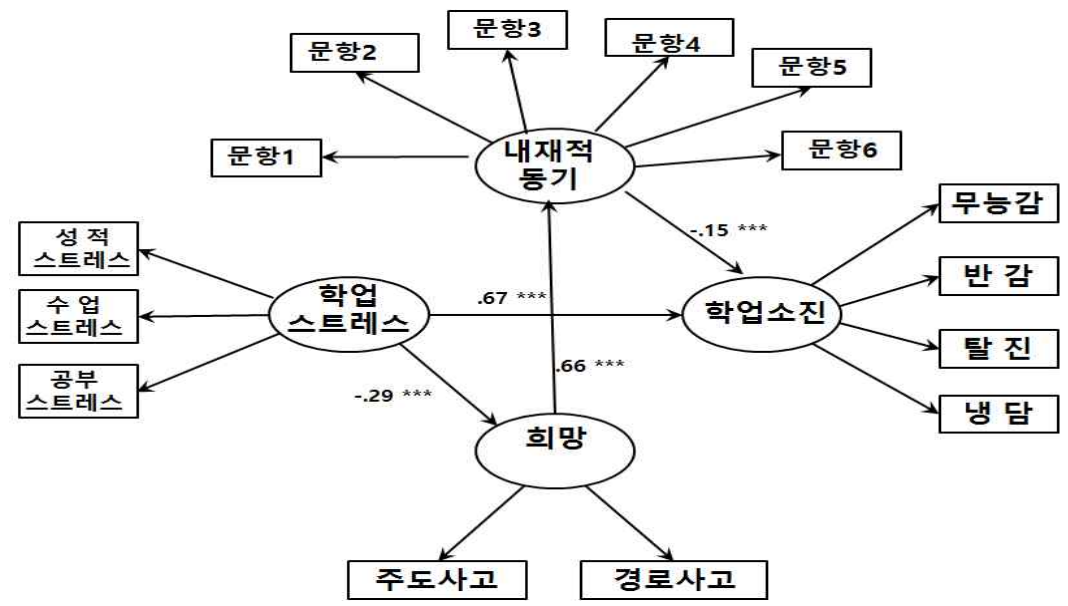

[그림 4] 경쟁 모형2-1 (비표준화경로계수)

<표 4> 학업스트레스와 학업소진의 관계에서 희망과 내재적 동기의 매개효과

\begin{tabular}{ccc}
\hline 매개변인 & 표준화 회귀계수 & 유의확률 \\
\hline 학업스트레스 $\rightarrow$ 희망 $\rightarrow$ 내재적 동기 & -.203 & .010 \\
\hline 희망 $\rightarrow$ 내재적 동기 $\rightarrow$ 학업소진 & -.084 & .010 \\
\hline
\end{tabular}

경쟁모형 2-1을 살펴보면 학업스트레스가 직접적으로 학업소진에 영향을 미치는 경로뿐만 아 니라 학업스트레스로 인해 학습자의 희망이 낮아지면 내재적 동기가 영향을 받아 학습자의 내재 적 동기가 감소되어 학업소진에 이르게 되는 간접 경로가 나타났다. 이는 학업스트레스가 학업소 진에 미치는 부정적인 영향력이 희망과 내재적 동기에 의해 변화될 수 있음을 보여주고 있다. 


\section{4. 남학생 집단과 여학생 집단 간의 구조적 관계 차이 분석 결과}

먼저 남학생 집단과 여학생집단의 구조모형(경쟁모형 2-1)에서 적합도는 <표 5>와 같다. 전반 적으로 남학생집단의 적합도지수가 여학생집단보다 좋은 것으로 나타났다.

<표 5> 성별 구조모형 적합도 지수비교

\begin{tabular}{rccccccc}
\hline & $\mathrm{x}^{2}$ & $d f$ & $p$ & CFI & TLI & GFI & RMSEA \\
\hline 남학생 & 185.16 & 83 & .000 & .944 & .929 & .903 & .075 \\
\hline 여학생 & 240.36 & 83 & .000 & .897 & .869 & .887 & .093 \\
\hline
\end{tabular}

남녀 두 집단 간 비제약 모형과 모든 경로를 등가제약한 모형의 적합도 지수는 <표 6>와 같 다. 두 모형의 $x^{2}$ 차이는 $5.51(\Delta d f=4)$ 로 $p<.05$ 에서 유의하지 않았으며 $\left(\Delta x^{2}<9.49, \Delta d f 4\right)$ 다른 적합도 지수는 두 모형에서 비슷하게 나타났는데, CFI는 .90에 약간 미치지 못하나 TLI>.90, GFI>.90으로 만족할 만한 적합도를 보여주었다. 이는 두 집단 간의 경로계수를 동일한 수준에서 해석할 수 있음을 의미한다.

<표 6> 구조모형의 적합도 지수

\begin{tabular}{cccccccc}
\hline & $\mathrm{x}^{2}$ & $d f$ & $p$ & CFI & TLI & GFI & RMSEA \\
\hline 비제약 & 420.61 & 166 & .000 & .894 & .904 & .924 & .059 \\
\hline 제약(모든경로) & 426.12 & 170 & .000 & .893 & .906 & .924 & .058 \\
\hline
\end{tabular}

다음으로 모든 경로에 등가제약한 모형에서의 경로계수를 두 집단 간에 비교한 결과는 <표 $7>$ 와 같고, 남학생과 여학생 집단별 경로가 모두 유의하게 나타났다( $p<.01)$.

<표 7> 남학생 집단과 여학생 집단별 모수추정치

\begin{tabular}{ccc}
\hline & 남학생 집단 & 여학생 집단 \\
\cline { 2 - 3 } & 비표준화 계수 & 비표준화 계수 \\
\hline 학업스트레스 $\rightarrow$ 희망 & $-.206^{* * *}$ & $-.430^{* * *}$ \\
\hline 희망 $\rightarrow$ 내재적 동기 & $.669^{* * *}$ & $.623^{* * *}$ \\
\hline 내재적 동기 $\rightarrow$ 학업소진 & $-.147^{* *}$ & $-.153^{* * *}$ \\
\hline 학업스트레스 $\rightarrow$ 학업소진 & $.664^{* * *}$ & $.716^{* * *}$ \\
\hline
\end{tabular}

$* * * p<.001, * * p<.01$ 
두 집단의 경로계수간의 유의한 차이를 검증하기 위해 비제약 모형과 집단 간 등가제약한 모 형을 비교하였다. 그 결과는 <표 8>과 같이 학업스트레스에서 희망의 경로가 유의한 차이를 보 여주었다. 즉 학업스트레스 $\rightarrow$ 희망의 경로계수는 여학생 집단이 남학생 집단에 비해 유의하게 높았으며, 이는 여학생이 남학생에 비해 학업스트레스로 인해 희망이 더 많이 감소한다는 것을 보여준다.

<표 8> 비 제약모형과 집단 간 등가 제약모형들 간의 차이 비교 ( $\left.{ }^{*} p<.05\right)$

\begin{tabular}{lccc}
\hline 등가제약을 가한 경로 & 자유도의 변화량 & $\mathrm{x}^{2}$ 변화량 & TLI 변화량 \\
\hline 학업스트레스 $\rightarrow$ 희망 & 1 & $5.370^{*}$ & .001 \\
\cline { 1 - 3 } 희망 $\rightarrow$ 내재적 동기 & 1 & 0.092 & .001 \\
\cline { 1 - 3 } 내재적 동기 $\rightarrow$ 학업소진 & 1 & 0.006 & .001 \\
\cline { 1 - 4 } 학업스트레스 $\rightarrow$ 학업소진 & 1 & 0.165 & .001 \\
\cline { 1 - 3 } 모든 경로 & 4 & 5.511 & .002 \\
\hline
\end{tabular}

\section{$\mathrm{IV}$. 논의 및 결론}

본 연구의 목적은 일반계 고등학생을 대상으로 학업스트레스가 학업소진에 이르는 과정에서 희망과 내재적 동기의 역할을 탐색하는 것이었다. 또한 이들 변인의 구조적 관계가 성별에 따라 달라지는지에 대해 알아보았다. 연구목적을 달성하기 위해 경기, 영남, 호남 지역의 일반계 고등 학생 433명의 설문응답 결과를 분석하였다.

주요연구 결과와 시사점을 정리하면 다음과 같다.

첫째, 전체적으로 학업스트레스가 학업소진에 미치는 직접적인 영향력이 확인되었다. 또한 학 업스트레스가 학습자의 내재적 동기에 직접 영향을 주기보다는 학습자의 희망을 거쳐 내재적 동기에 영향을 주어 학업소진에 이르게 되는 간접효과가 통계적으로 유의하다는 것( $p<.05)$ 을 검 증하여 학업스트레스와 학업소진의 관계에서 내재적 동기와 희망이 부분 매개함을 확인하였다.

둘째, 주요 측정 변인 간 상관분석 결과를 살펴보면 학업스트레스와 내재적 동기, 학업스트레 스와 희망, 내재적동기와 학업소진, 희망과 학업소진의 관계에는 유의한 부적 상관이 나타났으 며, 내재적 동기와 희망, 학업스트레스와 학업 소진의 관계는 유의한 정적 상관이 나타났다. 하 위 요인별로 살펴보면, 대부분의 하위요인별 상관이 유의하게 나타나서, 학업스트레스가 높을수 록 희망과 내재적 동기는 낮아지고 학업소진을 많이 경험할 수 있음을 보여주며, 내재적 동기와 희망이 높을수록 학업소진이 감소되고, 희망이 높을수록 내재적 동기가 증가함을 알 수 있었다. 
이는 지속적인 학업스트레스로 인해 학습자의 학업소진이 증가하고(김민애 외, 2010; 남상필.이 지연·장진이, 2012, 이은영, 2014), 학업동기가 낮아지지만(이민희.정태연, 2007; 조정은, 2001), 내 재적 동기와 희망이 증가할수록 학업 소진을 덜 경험한다는(고홍월, 2012; 장은주.이종연, 2014; 조현주, 2010; 진승하·신희천, 2010) 선행연구들을 지지하는 결과이다.

그러나 학업스트레스 중 성적스트레스와 내재적 동기의 상관이 유의하지 않은 부적 상관을 보임으로써, 성적에 대한 스트레스는 내재적 동기와 무관할 수 있는 가능성을 시사한다. 이는 성적은 학업에 대한 외적 결과이기 때문에, 외적인 결과인 성적으로 인한 스트레스는 과제를 더 깊이 알고자 하는 자발성에 기초하는 내재적 동기와 유의한 관계가 없을 수도 있음을 경험적으 로 보여주는 결과이므로, 이 결과에 대하여는 다양한 학생들을 대상으로 하는 후속연구들을 통 해 지속적으로 검증할 필요가 있다.

셋째, 학업소진에 영향을 미치는 요인으로 학업스트레스, 내재적 동기, 희망의 구조적 관계를 나타내는 [그림 4]를 통해 학업스트레스가 학업소진에 직접적인 영향을 미칠 뿐 만 아니라, 학업 스트레스가 학습자의 희망에 영향을 주고 다시 내재적 동기에 영향을 주어 학업소진에 이르게 되는 간접 경로에 대한 통계적 유의성을 확인하여 희망과 내재적동기가 학업스트레스와 학업소 진의 관계를 부분 매개한다는 것을 보여주었다. 좀 더 구체적으로 살펴보면 학업스트레스가 내 재적 동기에 미치는 직접적인 영향력과 희망이 학업소진에 미치는 직접적인 영향력은 유의하지 않았는데, 이는 높은 학업스트레스가 내재적 동기를 직접 낮추기 보다는 학습자의 희망을 감소 시켜 내재적 동기에 영향을 주고 있음을 나타내며, 학습자의 희망수준에 따라 학업소진이 직접 영향 받기보다는 학습자의 높은 희망이 내재적 동기를 증가시켜서 학업소진을 덜 경험할 수 있 음을 보여준다.

개인이 관심을 보이고, 자신의 능력을 발휘하여, 최적의 도전을 추구하고 달성하려는 성향 (Deci \& Ryan, 1985)인 내재적 동기는 여러 연구에서 학업스트레스와 부적 상관(김부미, 2014; 이민희.정태연, 2007; 조정은, 2011)을 나타낸다고 보고하고 있다. 그러나 [그림 4]에서 보는 것과 같이 학업스트레스와 내재적 동기의 관계를 분석할 때 희망을 포함하면, 학업스트레스가 내재적 동기에 미치는 영향력이 크게 감소하였다. 이러한 결과는 학업스트레스가 내재적 동기에 직접 영향을 주기보다는 희망을 통해 간접적으로 영향을 미친다는 것을 시사한다. 이는 자신을 목표 에 도달하기 위한 능력을 가진 주도적 존재로 인식하고 목표를 향한 다양한 경로를 생성하고 실행할 수 있다고 지각하는 희망 수준에 따라 학업스트레스가 내재적 동기에 미치는 영향력이 달라질 수 있음을 나타낸다. 학업수준에 따라 스트레스가 학업동기에 미치는 영향력이 달라진다 는 것을 보여준 김부미(2014)의 연구에서는 성적이 낮은 집단인 경우 학업스트레스가 무동기와 자율동기를 더 많이 설명하고, 성적이 높은 집단인 경우 통제동기를 더 많이 설명한다고 나타났 는데 이는 학업스트레스가 학습자의 다른 내적 특성과 연관되어 동기에 영향을 미친다는 것을 
보여준다. 이러한 내적 특성 중 하나가 희망이라고 볼 수 있을 것이다.

한편 여러 연구에서 희망이 학업소진과 부적 상관을 나타낸다고 보고하고 있고 본 연구에서 도 상관분석에서는 선행연구들과 일치되는 결과를 얻었다(진승하.신희천, 2010; 장은주.이종연, 2014). 그러나 학업 스트레스, 내재적 동기, 희망, 학업소진을 포함하여 분석한 구조모형에서는 희망이 학업소진에 직접 영향을 주기보다는 내재적 동기를 거쳐 간접적으로 영향을 미친다는 것을 보여주었다. 이는 목표를 향한 추진력과 달성가능한 방법의 소지여부에 대한 평가인 희망 이 학업소진에 직접 영향을 미치기 보다는 학습에 대한 내재적 동기를 유발하여 학습자의 주관 적 안녕 상태인 학업소진에 영향을 미치게 된다는 것을 보여준다. 희망이 높은 학습자는 학업스 트레스 상황에서 자신이 주체가 되어 해결하겠다는 의지를 보이고 실패보다는 성공하기 위한 방법을 찾는데 초점을 맞추어 학습에 대한 긍정적인 정서를 유지하고 사회적 지지망에 도움을 요청할 것이며(Snyder, 1994; 2002), 학습에 대한 긍정적인 정서로 인해 내재적 동기가 높아질 수 있고 그로 인해 학업소진이 낮아질 수 있다.

넷째, 남학생 집단과 여학생 집단 간 변인들의 구조적 관계의 차이는 없었지만 경로계수의 차이가 나타났다. 여학생 집단이 남학생 집단에 비해 학업스트레스에서 희망에 이르는 경로계수 가 유의하게 높았는데 이는 학업스트레스가 여학생의 희망 수준에 남학생보다 더 큰 영향을 미 칠 수 있음을 보여준다. 여학생의 희망수준이 남학생의 희망수준보다 학업스트레스에 의해 민감 한 영향을 받는다는 본 연구의 발견은 성에 따라 차별화된 학업 스트레스 조절 프로그램이 필요 하고 특히 여학생의 학업스트레스에 대한 보다 집중적인 관심이 필요하다는 것을 나타내며, 아 울러 무엇으로 인해 남학생보다 여학생의 학업스트레스가 희망에 보다 강한 영향을 미치는지에 대한 후속연구의 필요성을 시사한다.

다섯째, 본 연구의 결과에서 알 수 있듯이 학생들의 학업소진을 막기 위해서는 학업 스트레스 조절 능력, 학업에 대한 내재적 동기, 희망수준이 높아질 필요가 있다. 이들 각각을 위한 프로그 램들은 적지 않게 개발되어 있다(스트레스 대처훈련의 예: 김정호.이경숙, 2000; 김은주·천성문. 이영순, 2012, 학습동기 증진 프로그램의 예: 김형국, 2013; 박진희, 2012, 희망증진 프로그램의 예: 박문규·이영순, 2011, Lopez et al., 2009). 그러나 고등학교 현장에서는 그 필요성을 인정하면 서도 교과 학습 시간을 할애하여 학업스트레스 감소나 학업동기 증진 및 희망 증진 등의 심리지 원을 위한 시간을 따로 마련하기는 쉽지 않다. 그러나 최근 입시준비방법이 다양화되고 학생들 의 창의적인 체험활동과 자치활동이 장려되고 있는 분위기를 활용하여, 학업스트레스 감소 프로 그램, 학습동기 증진 프로그램, 희망증진 프로그램 등을 학생들에게 보급하려는 노력을 해보거 나 멘토링 프로그램을 활용하여 필요한 학생에게 제공하는 것(김동일 외, 2010)은 고려해볼만한 시도라고 볼 수 있다. 
본 연구의 의의는 다음과 같다.

첫째, 고등학생의 학업스트레스가 학업소진에 이르는 과정에서 내재적 동기, 희망의 역할을 경 험적으로 확인하였다는 점이다. 이러한 결과는 누적된 학업스트레스로 인해 학업소진을 많이 경 험할 수 있는 고등학생들의 학업소진 방지를 위해 집중해야할 심리내적 특성을 보여주고 있다. 이는 고등학생의 학업소진 예방을 위해서는 학업스트레스 관리 및 감소를 위한 전략과 함께 학 습자의 내적 특성인 내재적 동기와 희망을 증가시키기 위한 전략이 필요하다는 것을 나타낸다.

둘째, 학업스트레스가 학업소진에 이르는 과정에서 희망의 역할을 탐색했다는 점이다. [그림 4]에서는 학업스트레스가 학습자의 희망을 통해 내재적 동기에 영향을 주어 학업소진에 이르게 됨을 보여주었다. 이는 지속적인 학업스트레스 상황에서도 학습자의 희망 수준이 높으면 내재적 동기가 낮아지지 않으며, 학업소진을 경험하지 않을 수 있어 희망의 영향력을 확인해 주는 것이 고, 또한 내재적 동기 유발을 위해 희망이 중요한 역할을 할 수 있음을 나타내 준다. 최근 학업스 트레스 감소 및 학업동기 향상 프로그램들에 대한 연구가 많이 진행되고 있다(김동원, 2013). 그 러나 학업소진 감소를 위해서는 두 가지를 통합한 연구가 필요하고 더불어 학습자의 희망수준 향상을 위한 연구도 필요하다는 것을 보여주고 있다.

셋째, 학습자의 낮은 내재적 동기가 학업 소진에 영향을 줄 수 있음을 보여주었다. 최근 연구 결과들은 학업스트레스가 우울, 자살 등에 직접적으로 영향을 미치는 것이 아니라 학업소진을 통해 나타난다고 설명한다(Koeske \& Koeske, 1991). 따라서 학업소진 감소를 위한 적극적인 대 처가 필요하고 그에 대한 하나의 방안으로 내재적 동기를 증진 시키는 것이 중요하다는 것을 나타내 준다.

이러한 여러 가지 의의에도 불구하고 본 연구는 학업스트레스가 학업소진에 이르는 경로에서 개인 내적 변인인 희망과 내재적 동기에 국한하여 그 역할을 탐색하였다는 한계를 가진다. 따라 서 학업스트레스가 학업소진에 이르는 경로에 영향을 주는 개인 외적 변인 및 또 다른 개인 내 적 매개변인에 대한 추가 탐색이 필요하며, 아울러 본 연구의 결과가 학업스트레스 상황에서 학 생들의 학업소진 예방을 위해 활용되기 위해서는 학업 스트레스와 다른 매개변인을 밝힌 선행 연구들(예, 박일경 외, 2010, 신병창, 2012; 신혜진·유금란, 2014; 이자영, 2010a, 조한익.이현아, 2010; 한은아 외, 2011; Maslach \& Jackson, 1981; Yang, 2004)을 종합적으로 고려하여야 할 것이 다. 또한 본 연구에서는 고등학교 학생들의 학년 특성을 동일하다고 가정하고 분석을 실시하였 기 때문에 학업스트레스, 학업소진, 희망과 내재적동기의 학년별 특징을 반영하지 못하였다. 추 후에는 수능을 앞둔 고등학교 3학년의 특징을 포함한 다른 학년의 특징을 반영하여 비교하는 연구가 진행될 필요가 있을 것이다. 


\section{참고문헌}

강명희(2013). 청소년의 학업스트레스와 심리적 안녕감의 관계에서 희망 및 자아탄력성의 매개 효과. 박사학위논문, 대구한의대학교.

강명희, 이수연(2012). 희망과 자아탄력성이 청소년의 학업스트레스에 미치는 영향. 미래청소년 학회지, 9(4), 281-302.

강이영(2002). 상담과정 희망척도 개발과 적용. 박사학위논문, 성균관대학교.

고경희(2003). 자기결정성 이론에 따른 학업적 자기조절 동기 유형 탐색. 석사학위논문, 이화여자 대학교.

고재홍, 윤경란(2007). 청소년의 스트레스와 자살 생각, 자아탄력성의 완충 효과. 한국 청소년연 구,18(1), 185-212.

고홍월(2012). 대학생 학습동기 유형에 따른 학업소진과 학업적 실패내성의 차이. 아시아교육연 구, 13(1), 125-147.

김남희(2006). 희망과 사회적 지지, 대처방식이 심리적 안녕감에 미치는 영향. 석사학위논문, 가 톨릭대학교.

김동일, 정여주, 허은, 방나미(2010). 학업적 자기효능감과 정서적 공감능력 증진을 위한 멘토링 프로그램 개발. 상담학연구, 11(2), 583-602

김동원(2013). 학업스트레스 감소 프로그램과 학업동기 증진 프로그램을 통합한 학업상담 프로 그램의 효과. 놀이치료연구, 17(3), 129-149.

김미경, 김양희, 황사라, 정익중(2012). 고등학생의 성적이 학업스트레스에 미치는 영향: 성별 조 절효과를 중심으로. 청소년복지연구,14(4), 165-187.

김민애, 이상민, 신효정, 박양민, 이자영(2010). 과중한 학업요구와 학업소진과의 관계: 통제감의 역할을 중심으로. 한국심리학회지: 학교, 7, 69-84.

김부미(2014). 중학생의 학업스트레스가 학업동기 유형 및 수학학습동기의 관계 분석. 교과교육 연구, 18(1), 157-180.

김아영(2010). 학업동기: 이론연구와 적용. 학지사.

김아영, 오순애(2001). 자아결정성 정도에 따른 동기 유형의 분류. 교육심리연구, 15(4), 97-119. 김영실(2012). 초등학생의 과중한 학업요구와 학업소진과의 관계에서 자아존중감의 매개효과. 석사학위논문, 인천대학교.

김은주, 천성문, 이영순(2012). 과학고 학생들을 위한 학업스트레스 대처훈련 프로그램의 개발 및 효과. 한국교육논단, 11(1), 127-148. 
김정호, 이경숙(2000). 학업스트레스 대처훈련이 고등학생의 학업스트레스와 학업성취에 미치는 효과. 한국심리학회지 건강, 5(1), 43-59.

김향란(2012). 희망이 중학생의 성취동기, 진로장벽, 진로태도성숙에 미치는 영향. 석사학위논문, 배제대학교.

김현희(2009). 성별에 따른 학업스트레스와 시험불안과의 관계연구. 석사학위논문, 한국외국어대. 김형국(2013). 농촌 실업계 고등학생들의 자기주도적 영어 학습을 위한 학습모형 연구-자율성을 중심으로-. 교육이론과 실천, 23, 65-81.

남상필, 이지연, 장진이(2012). 학업성취 압력이 학업소진에 미치는 영향: 자기통제감의 조절효 과를 중심으로. 아동교육, 21(3), 219-230.

명혜원(1999). 중학생의 학년 및 성별에 따른 내적동기와 학업성취도 연구. 석사학위논문, 동아대 학교.

모상현, 김미영(2009). 학업 스트레스에 영향을 미치는 내·외재적 변인 탐색과 보호 요인 효과에 관한 연구. 교육의 이론과 실천, 14(2), 1-19.

문경숙(2006). 학업스트레스가 청소년의 자살충동에 미치는 영향. 아동학회지, 27(5), 143-157. 박문규, 이영순(2011). 희망증진 집단상담 프로그램이 중학생의 학습동기와 목표지향성에 미치 는 영향. 상담학연구, 12(2), 505-522.

박병기, 박선미(2012). 학업스트레스 척도의 개발 및 타당화. 교육심리연구, 26(2), 563-585. 박병기, 이종욱, 홍승표(2005). 자기결정성 이론이 제안한 학습동기분류형태의 재구성. 교육심리 연구, 19(3), 699-717.

박일경, 이상민, 최보영, 김원영, 이자영(2010). 5요인 성격특성과 학업소진과의 관계. 한국심리 학회지: 사회 및 성격, 24, 81-93.

박진희(2012). 인지행동 문학치료가 고등학생의 학습된 무력감과 학업성취동기에 미치는 영향. 석사학위논문, 경북대학교.

손향숙(2002). 고등학교의 스트레스와 스트레스 대처방식에 관한 연구. 석사학위논문, 전남대학 교.

송주영, 이희경(2013). 초심상담자의 직무스트레스와 심리적 소진의 관계. 인간이해, 34(1). 93-110.

신병창(2012). 초등영재아동과 일반아동의 부모의 학업성취압력과 학업기대스트레스가 학업소 진에 미치는 영향. 석사학위논문, 인천대.

신현숙, 송종화, 김현주(2005). 대입수험생의 학업 스트레스, 비관성 및 사회적 위축의 관계모형 검증. 전남대학교 교육문제 연구소, 교육연구, 28, 121-142.

신혜진, 유금란(2014). 중학생의 학업스트레스와 학업소진과의 관계에서 유대감의 매개효과, 청 소년학연구, 21(1), 367-393. 
안도희, 최혜림(2012). 고등학생의 학업동기 및 사회적 지지와 학업성취와의 관계. 한국교육문 제연구, 30(2), 145-164.

이경숙, 김정호(2000). “학업스트레스 대처훈련이 고등학생 학업스트레스와 학업성취에 미치는 효과". 심리학과 졸업 논문, 덕성여자대학교.

이민희, 정태영(2007). 청소년용 학습동기 척도의 개발 및 타당화. 한국청소년연구, 18(3), 295-321.

이상민(2010). 초·중·고등학생의 학업소진 진행과정 및 경로분석. 집문당: 아산재단 연구총서 제331집.

이영복, 이상민, 이자영(2009). 학업소진 척도개발. 한국교육학 연구, 15(3), 59-78.

이은영(2014). 학업요구와 학업소진 관계에서 학업통제감의 조절효과. 석사학위논문, 고려대학교. 이은희, 최태산, 서미정(2000). 남녀 청소년들의 우울에 미치는 학교 스트레스, 자아존중감, 부모 자녀 의사소통 및 부모의 내재적 지원 효과. 한국 심리학회지:상담과 심리치료, 12(2), 69-84.

이자영(2010a). 과도한 학업요구와 학업소진의 관계에서 성취목표의 매개효과. 상담학연구, 11(4), 1551-1565.

이자영(2010b). 나이에 따른 학업소진 차이 검증. 박사학위논문, 고려대학교.

이지현, 이정윤(2009). 청소년의 학업스트레스와 자살생각의 관계. 상담학연구, 10(2), 1113-1126.

이희경(2007). 중학생의 희망과 공감 하위집단에 따른 심리적 안녕감의 차이. 한국심리학회지: 상담 및 심리치료, 19(3), 751-766.

장은주, 이종연(2014). 희망의 주도사고 및 경로사고와 고등학생의 학업성취 및 주관적 안녕 변 인들 간의 구조적 관계. 상담학연구, 15(1), 371-392.

전혜진, 김영갑(2011). 사이버대학교 학생의 학업소진에 대한 인식이 학업성취도와 학업지속의 향에 미치는 영향 : $\mathrm{H}$ 사이버대학교 호텔관광경영학과재학생 중심으로. 관광레저연 구, 23(8), 475-491.

정지영, 김희화(2005). 아버지와 어머니의 양육행동이 청소년의 자율학업동기에 미치는 영향. 대 한가정학회지, 43(9), 163-173.

조강래(2007). 고3 학생들의 학업스트레스원에 따른 학업스트레스 증상과 대처방식: 일반계 고 등학교 남녀 비교를 중심으로. 석사학위논문, 경상대학교.

조정은(2011). 청소년의 학업적 자기효능감과 자기결정성동기가 학업스트레스에 미치는 영향. 석사학위논문, 단국대학교.

조주연, 김명소(2013). 초등학생의 학업소진 및 학업열의에 관한 남녀 차이 연구. 한국심리학회 지; 여성, 18(4), 477-497. 
조한익(2010). 성취목표지향성, 희망 및 학업성취도의 구조적 관계와 성별에 따른 잠재평균분석. 교육심리연구, 24(4), 853-873.

조한익(2012). 학교생활적응과 학업성취도에 영향을 미치는 성취목표지향성, 희망 및 학습전략 의 구조적 관계. 한국심리학회지: 학교, 9(3), 465-483.

조한익, 이현아(2010). 완벽주의와 학업소진 및 학업열의와의 관계에 있어서 성취목표의 매개효 과. 청소년학연구, 17(12), 131-154.

조현주(2010). 희망이 생활스트레스와 정신병리, 삶의 만족도에 미치는 영향. 한국심리학회지: 임상, 29(3), 839-852.

진승하, 신희천(2010). 스트레스와 우울의 관계에서 희망의 조절효과: 희망의 2요인 모델을 중심 으로. 상담학 연구, 11(4), 1519-1535.

통계청(2010). 사회조사 등을 통해 바라본 우리나라 고3의 특징. http://kostat.go.kr.

한국교육과정 평가원(2014). PISA 2012 결과에 나타난 우리나라 학생들의 성취 특성: ORM 2014-14.

한은아, 김보영, 이상민, 신효정(2011). 부모양육 태도와 부모소진 및 자녀 학업소진의 관계. 안 암교육학회, 17(1), 270-293.

한태영(2005). 청소년의 학교 장면 스트레스 성격 및 정서 지능의 조절효과. 한국심리학회지, 12(2), 177-197.

황혜정(2006). 초등학생과 중학생의 스트레스와 이에 영향을 미치는 변인에 관한 연구. 초등교 육연구, 19(1), 193-215.

Adelabu, D. (2008). Future time perspective, hope, and ethnic identity among African American adolescents. Urban Education, 43, 347-360.

Bakker, A. B., Schaufeli, W. B., Demerouti, E., Janssen, P. P. M., Hulst, R. V. D., \& Brouwer, J. (2000). Using equity theory to examine the difference between burnout and depression. Anxiety, Stress \& Coping, 13, 247-268.

Barnum, D., Snyder, C., Rapoff, M., Mani, M., \& Thompson, R. (1998). Hope and social support in the psychological adjustment of children who have survived burn injuries and their matched controls. Children's Health Care, 271), 15-30.

Bellingrath, S., Weigl, T., \& Kudieka, B. M. (2008). " Cortisol dysregulation in school teachers in relation to burn out, vital exhaustion, and effort-reward-imbalance". Biological Psychology, 78(1), 104-113.

Bland, R., \& Darlington, Y. (2002). The nature and sources of hope: Perspectives of family caregivers of people with serious mental illness. Perspectives in Psychiatric Care, 38(2), 
61-68.

Bolland, J. (2003). Hopelessness and risk behavior among adolescents living in high poverty inner-city neighborhoods. Journal of Adolescence, 26, 145-158.

Bunston, T., Mings, D., Mackie, A., \& Jones, D. (1995). Facilitating hopefulness: The determinants of hope. Journal of Psychosocial Oncology, 13(4), 79-103.

Carvajal, S., Clair, S., Nash, S., \& Evans, R. (1998). Relating optimism, hope, and self-esteem to social influences in deterring substance use in adolescents. Journal of Social \& Clinical Psychology, 17, 443-465.

Chang, V., Bendel, T., Koopman, C., McGarvey, E., \& Canterbury, R. (2003). Delinquents' safe sex attitudes. Criminal Justice and Behavior, 30, 210-229.

Ciarrocchi, J., Dy-Liacco, G., \& Deneke, E. (2008). Gods or rituals? Relational faith spiritual discontent, and religious practices as predictors of hope and optimism. Journal of Positive Psychology, 3(2), 120-136.

Davis-Maye, D., \& Perry, T. (2007). Momma's girl: The significance of maternal figure support in the development of hope for African-American girls. Journal of Human Behavior in the Social Environment, 15, 307-328.

Deci, E. L., \& Ryan, R. M. (1985). Intrinsic motivation and self-determination in human behavior. N. Y. : Plenum Press.

Juntnen, C. L., \& Wettersen, K. B. (2006). Work hope: Development and initial validation of a measure. Journal of Counseling Psychology, 53(1), 94-106.

Karasek, R. (1979). "Job demands, job decision latitude, and mental strain; Implication for job redesign". Administrative Science Quarterly, 285-308.

Kenny, M. E., Walsh-Blair, L. Y., Blustein, D. L., Bempechat, J., \& Seltzer, J. (2010). Achievement motivation among urban adolescent: Work Hope, autonomy support, and achievement-related beliefs, Journal of Vocational Behavior 77, 205-212.

Kiuru, N., Aunola, K., Nurmi, J.-E., Leskinen, E., \& Salmela-Aro, K. (2008). " Expanding education and improving odds? Participation in higher education in Finland in the 1980s and 1990s". Act a Sosiologica, 44(1), 71-181.

Koeske, G. F.. \& Koeske, R. D. (1991). Underestimation of social support buffering Journal of Applied Behavioral Science, 274), 475-489.

Lazarus, R. S., \& Folkman, S. (1984). "Coping and adaptation", Gentry, WD (Eds.), Handbook of Behavioral Medicine: 11-21.

Li, J., Yang, W., \& Cho, S. (2006). "Gender differences in job strain, effort-reward imbalance, 
and health functioning among Chinese physicians". Social Science \& Science, 1066-1077.

Lopez, S. J., Rose, S., Robinson, C., Marques, S. C., \& Pais-Ribeiro, J. L. (2009). Measuring and promoting hope in school children. In R. Gilman, E. S. Huebner, \& M. J. Furlong (Eds.), Handbook of positive psychology in the schools (pp. 37-51). Mahwah, NJ: Lawrence Erlbaum.

Mahon, N., Yarcheski, A., \& Yarcheski, T. (2004). Social support and positive health practices in early adolescents: A test of mediating variables. Clinical Nursing Research, 13, 216-236.

Maslach, C., \& Jackson, S. E. (1981). Maslach Burnout Inventory(2nd), Palo Alto, CA: Consulting Psychologists Press.

Meier, S. F.,\& Schmeck, R. R. (1985). The burned-out college student; a descriptive profile. Journal of College Student Personnel, 1, 63-69.

Padilla-Walker, L., Hardy, S. A., \& Christensen, K. J. (2011). Adolescent hope as a mediator between parent-child connectedness and adolescent outcomes. Journal of Early Adolescence, 31(6), 853-879.

Ramist, L. (1981). College student attrition and retention. Findings(ETS), 6, 1-4.

Reeve, J. (2006). "Teachers as facilitators: What autonomy-supportive teachers do and why their students benefit". The Elementary School Journal, 106(3), 225-236.

Ryan, R. M., \& Connell, J. P. (1989). Perceived locus of causality and internalization: Examining reasons for acting in two domains. Journal of Personality and Social Psychology, 57. 749-761.

Schaufeli, W. B., Martez, I. M., Marques Pinto, A., Salanova, M.,\& Bakker, A. B. (2002). Burnout and engagement in university students: A cross-national study. Journal of Cross-Cultural Psychology, 33, 464-481.

Shorey, H., Snyder, C., Yang, X., \& Lewin, M. (2003). The role of hope as a mediator in recollected parenting, adult attachment, and mental health. Journal of Social \& Clinical Psychology, 22, 685-715.

Siegrist, J., Peter, R., Jurge, A., Cremer, P., \& Seidel, D. (1990). "Low status control, high efforts at work and is chemic heart disease: prospective evidence from blue-collar men". Social Science and Medicine, 23, 1127-1134.

Snyder, C. R. (1994). The psychology of hope: You can get there from here. New York: The Free Press. 
Snyder, C. R. (2002). Hope Theory: Rainbow in the mind. Psychological Inquiry, 13(4), 249-275.

Snyder, C. R., Harris, C., Anderson, J. R., Holleran, S. A., Iriving, L. M., Sigmon, S. T., Oshinoubu, L., Gibb, J., Langelle, C., \& Harney, P. (1991). The will and the ways: Development and validation of an individual-differences measures of hope. Journal of Personality and Social Psychology, 60, 570-585.

Snyder, C. R., Shorey Hal S., Jennifer Cheavensm Kimberley Mann Pulvers, Virgil H. Adams III, \& Cynthia Wiklund. (2002). Hope and Academic Success in College. Journal of Educational Psychology, 94(4), 820-826.

Snyder, C. R., Sympton, S. C., Ybasco, F. C., Borden, T. F., Babyak, M. A., \& Higgins, R. L.(1996). Development and validation of the State Hope Scale. Journal of personality and social psychology, 70(2), 321.

Wilks, S. E. (2008). Resilience amid academic stress: The moderating impact of social support among social work students. Advances In Social Work, 9(2), 106-125.

Yang, H. (2004). Factors affecting student burnout and academic achievement in multiple enrollment programs in Taiwan's technical-vocational colleges. International Journal of Educational Development, 24, 283-301.

Yarcheski, A., Mahon, N., \& Yarcheski, T. (2001). Social support and well-being in early adolescents: The role of mediating variables. Clinical Nursing Research, 10, 163-181.

You, S., Furlong, M., Felix, E., Sharkey, J., Taningawa, D., \& Green, J. (2008). Relaions among school connectedness, hope, life satisfaction, and bully victimization. Psychology in the Schools, 45, 446-460.

\section{* 논문접수 2014년 11월 4일 / 1차 심사 2014년 12월 8일 / 게재승인 2014년 12월 15일}

* 강혜정: 서울대학교 간호대학 간호학과를 졸업하고 전북대학교 일반대학원 교육학과에서 석사학위를 취득하였으며, 동대학 원 박사과정에 재학 중이다.

*E-mail: khj-0520@hanmail.net

* 강성현: 전북대학교 사범대학 교육학과 졸업하고, 전북대학교 교육대학원 교육학과 석사학위 취득 및 동대학원 박사과정을 수료하였으며 전북사대부설 고등학교에서 교사로 재직 중이다.

*E-mail: sung5753@hanmail.net

* 임은미: 이화여자대학교 사범대학 교육심리 학과를 졸업하고, 서울대학교 대학원 교육학과에서 석 - 박사학위를 취득하였으 며, 현재 전북대학교 교육학과 교수로 재직 중이다. 주요 저역서로는 진로상담이론(공저, 2010 , 학지사), 다문화 상담(공역, 2011, 학지사) 등이 있다.

*E-mail: tgeunmi@hanmail.net 


\section{Exploring the Structural Relationship among Academic Stress, Hope, Intrinsic Motivation and Academic Burn-out of High School Student and the Gender Difference}

Kang, Hye-Jeong*

Kang, Seong-hyeun**

Lim, Eun-mi ${ }^{* * *}$

The purpose of this research was to investigate the structural relationships among academic stress, academic burn-out, intrinsic motivation, and hope of Korean high school students by gender. To achieve the purpose, a survey was administered to male ( $\mathrm{N}=222)$ and female $(\mathrm{N}=221)$ high school students in Kyunggi, Youngnam, and Honam province in South Korea. The results were as follows; Academic stress had a direct effect on academic burn-out. And academic stress also had a significant indirect effect on academic burnout. i.e., the influence of academic stress on the academic burnout was reduced by hope and intrinsic motivation. The results also indicated that female high school students' academic stress had some more negative influence on their hope as compared to males. Both limitations of this study and suggestions for further studies were discussed with the implications of these findings.

Key words: High School Student, Academic Stress, Academic Burn-out, Hope, Intrinsic Motivation

\footnotetext{
* First author, Ph.D Candidate, Chonbuk National University

** Second author, Ph.D Candidate, Chonbuk National University

*** Corresponding author, Professor, Chonbuk National University
} 